\title{
Political Leadership and Global Governance: Structural Power Versus Custodial Leadership
}

\author{
Katherine Morton ${ }^{1}$ (iD
}

Received: 17 September 2017/ Accepted: 19 September 2017/Published online: 27 November 2017

(C) The Author(s) 2017. This article is an open access publication

\begin{abstract}
This article examines the role of political leadership within the realm of global governance. Drawing upon relevant theories of political agency, particular attention is given to addressing the relationship between leadership and collective action. A two-level analysis of institution building in relation to maritime security and economic trade and investment reveals both strengths and weaknesses in practice. A review of the Law of the Sea Convention and the Multilateral Investment Agreement provides a salutary reminder that material power does not translate easily into dominating the rules of international conduct. The cases of the Asia Pacific Economic Cooperation Forum and the Trans-Pacific Partnership further highlight the importance of mixed sources of political leadership in responding to economic challenges at the regional level. The policy implication for both the United States and China is that taking the lead in Global Governance, either jointly or multilaterally, will require a renewed focus upon custodial stewardship that aims to realign interests with long-term goals.
\end{abstract}

Keywords Political leadership - Global governance - Structural power - Custodial stewardship · International institutions

\section{Introduction}

It is commonly understood amongst scholars of International Relations that leadership matters most at times of crisis, strategic vulnerability, or when international conditions are fluid. Yet, the particular form of political leadership that is required to consolidate collective action during periods of transition is less

Katherine Morton

katherine.morton@sheffield.ac.uk

1 The University of Sheffield, Sheffield, UK 
well understood. In the current era, growing power competition, especially between the United States and China, fuels anxieties that international cooperation will gradually decline. It is also tempting to conclude that a leadership vacuum is likely to emerge in response to mounting global challenges. The imperative to re-balance interests and responsibilities between dominant and emerging powers will be difficult to achieve in the immediate term. Furthermore, it can no longer be taken for granted that a liberal consensus exists over support for collective action at the international level. US withdrawal from the Paris Climate Agreement and the TransPacific Partnership under the new Trump Administration, together with the United Kingdom's exit from the European Union, suggest a growing tension between domestic and international obligations on the part of Western liberal states. The question that arises is whether a more positive trend towards collaboration could gather momentum to offset rising parochialism in the international arena.

Building upon earlier theories of political agency, this article examines the relationship between charismatic, structural, and collaborative forms of leadership within the realm of global governance. Particular attention is given to addressing the question of what political leadership entails to advance our understanding of the political capacity for collective action. A two-level analysis of the role of leadership in institution building highlights both strengths and weaknesses. A review of the Law of the Sea Convention and the multilateral investment agreement (MAI) provides a salutary reminder that material strength does not translate easily into dominating the rules of international conduct. It is essentially a collective enterprise. At the regional level, the cases of the Asia Pacific Economic Cooperation Forum (APEC) and the Trans-Pacific Partnership (TPP) further highlight the importance of mixed political leadership in responding to regional challenges relating to trade and investment.

In conclusion, the article argues that structural power is an important but inadequate source of leadership in global governance. Instead, diverse sources of structural power, intellectual capital, and custodial stewardship are all likely to enhance political capacity in the contemporary era. Above all, a commitment towards custodial stewardship is now both timely and politically prudent in light of rapidly shifting international circumstances, especially within the global economy.

Contrary to the expectations of some studies that predict greater gridlock within global governance, the departure point for this article is that we are likely to see harder bargains rather than stronger conflicts over leadership. This is primarily for three reasons: first, global governance is currently in a state of flux and tensions remain over its future trajectory, but this does not mean that the unraveling of institutional arrangements is inevitable. On the contrary, the literature on emerging powers and global governance suggests that greater efforts are now being made to promote equality of representation in global institutions, especially in regard to integrating major emerging economies into leadership roles. ${ }^{1}$ The G20 in particular stands out as an exemplar of shifting the balance of interests more in favour of developing countries, although this reformist approach is still hampered by the struggle to create a greater convergence over national and international priorities.

\footnotetext{
${ }^{1}$ For good overviews see Alexandroff and Cooper (2010) and Cooper and Kiewicz (2008).
} 
Second, the history of institution building suggests that political leadership matters most at times of crisis; and that crises often act as catalysts for institutional innovation. The United Nations is a classic example of how a grand vision to build a peaceful world free from the threats of genocide and economic dislocation emerged from the ashes of a devastating world war. Third, we are currently witnessing a trend towards collaborative leadership that does not solely depend upon a single powerful state to sanction collective action. In today's world, a more pluralistic form of global governance provides an essential means of responding to the risks and opportunities arising from higher levels of interdependence between states and peoples. This is not to suggest that functional imperatives now dominate the global governance agenda. Rather, it is to recognise that in the contemporary era no individual state, no matter how powerful, has the political capacity to govern the world unilaterally.

The salient question is no longer whether but rather how a more collaborative form of global leadership can endure. To address this question we shall first consider the relevant theories of political leadership followed by a discussion of the lessons drawn from the actual practice of institution building in relation to maritime security and economic trade and investment. Dating back to the beginnings of the post-WWII international order, both these global issues offer a longer timeframe against which to assess changes and continuities. Given that to date existing studies have tended to focus upon international regimes, a further examination of institutional initiatives within the Asian regional context provides a more granular perspective. Finally, the selection of cases are illustrative rather than representative-involving both positive and negative experiences to control for any bias weighted towards the assumption that political leadership is always effective. My purpose in this article is to contribute to the contemporary debate over what political leadership entails, rather than address the more complex question of what makes political leadership effective.

\section{What Does Political Leadership Entail?}

Common to many theories of leadership in the study of International Relations is a conception of the relationship between leaders and followers under conditions of asymmetric power relations. In classical Western philosophy, political leadership is seen as being distinct from power domination in that the former requires an expressed willingness to follow on the part of other states and/or people, whereas the latter is dependent upon rule by coercion. In the modern era, the German sociologist Max Weber famously distinguished alternative sources of leadership derived from non-Western traditions. For example, in his classic treatise on Imperial China he argued that the charismatic nature of the Emperor (tao) was manifest in his personal strength that needed to be constantly proven in the eyes of the people. ${ }^{2}$ In his view, this did not equate with the recognition of the sovereignty of the people, but rather with the devotion of the people, especially at times of distress. ${ }^{3}$ While a

\footnotetext{
${ }^{2}$ Gerth and Mills (1958).

${ }^{3}$ Ibid. IX The Sociology of Charismatic Authority, p. 246.
} 
deeper discussion of the cultural determinants of leadership is beyond the scope of this article, Weber's seminal work on charismatic authority is a useful reminder of how individual personality traits affect leadership.

For the purpose of examining the role of political leadership within the realm of global governance, the framework presented below maintains a narrower focus on leadership understood as the capacity for collective action. Building upon existing studies it delineates three major forms of leadership-charismatic, structural, and collaborative - that to a lesser or greater extent play a meaningful role in advancing the governing system of rules, norms and institutions.

\subsection{Charismatic Leadership}

On January 18 1919, at a turbulent moment in world history, German's leading intellectual, Max Weber, declined to address the fate of the nation and instead focused his attention exclusively on the subject of 'Politics as Vocation.' In addressing the question of the justification for rule based upon the legitimate use of force he proposed three ideal types of political authority (1) traditional as exercised according to custom by patriarchs and patrimonial leaders (2) charismatic as denoted in the devotion to the leadership qualities of an individual, and (3) legal based upon rational rule and legal statutes. ${ }^{4}$

His aversion to both the Monarchist incompetency of Kaiser Wilhelm II and the realpolitik (power for power's sake) of Otto von Bismarck led him to focus particularly on the potential for charismatic authority as a counter-balance to Prussian bureaucracy and its overly rationalised mindset. Although predisposed towards the humanist tradition, his definition of charisma as a 'gift of grace' was borrowed from the theological teachings of Rudolf Sohm. ${ }^{5}$ Charisma in this sense was endowed with exceptional, if not divine qualities. This did not mean, however, that leadership could endure simply on the basis of the fascination of the individual. According to Weber, a capacity to constantly demonstrate strength constituted the essence of charismatic leadership. Critical to the Weberian ideal of charismatic leadership is the sense of mission. In his words:

Charisma knows only inner determination and inner restraint. A holder of charisma seizes the task that is adequate for him and demands obedience and a following by virtue of his mission... his charismatic claim breaks down if his mission is not recognised by those to whom he feels he has been sent' ${ }^{6}$

Over time the idea of charisma has lost its appeal in the study of political leadership, but it remains relevant as a counter-balance to structural realist interpretations of international order. During the Cold War, the study of leadership in International Relations was overshadowed by concerns over structural dynamics within the international system. Writing in 1991, following the collapse of the Soviet Union, Byman and Pollack in their article titled 'Let Us Now Praise Great

\footnotetext{
4 Owen and Strong (2004).

5 H. H. Gerth and C. Wright Mills. 1958. op.cit.

${ }^{6}$ Ibid. p. 246.
} 
Men' hailed the return of the Kissinger view of history in which personalities rather than impersonal forces bring about change in practice. Drawing upon a collection of historical case studies, they argued that the study of individuals in International Relations 'takes on added significance when power is concentrated in the hands of a leader, when institutions are in conflict, or at times of great change. ${ }^{7}$ More ambitiously, the authors claimed that individual leaders could also shape the broader determinants of international order in relation to the balance of power, domestic opinion, and bureaucratic politics. ${ }^{8}$ Putting aside the dubious claim that only great men can make a difference in history, such analyses of great statesmanship offer useful insights into the role of political agency, especially at times of crisis.

Such a perspective, however, suffers from the problem of ascribing too much agency to individual leaders; it takes for granted the idea of what constitutes great statesmanship, which is obviously prone to manipulation; and ignores the social context within which leadership takes place. To address this problem, more recently attention has focused upon rediscovering the importance of political legitimacy. For example, Joe Nye in his book 'The Powers to Lead' (2008) argues that leadership is not a fixed set of attributes, but instead moves with the times on the basis of leaders and followers rather than natural leaders under the guise of charismatic leadership. ${ }^{9}$ This emphasis upon the relational dimension of leadership has its origins in Western philosophical thought as discussed above, but in contrast to a traditional Weberian conception of charisma that takes for granted the appeal of a leader, this modern version is socially ascribed, knowledge-based, and more deeply institutionalised.

\subsection{Global Governance and Leadership}

Charismatic leadership in its modern form can perhaps best be regarded as a latent feature of global governance, especially if we retain the Weberian emphasis upon mission rather than become distracted with populist images akin to entertainment. For global governance theorists, political agency resides in multiple actors. Within diverse institutional settings, leadership is seen as a social process of bargaining, negotiation, and persuasion to achieve a common goal. This stands in stark contrast to dominant realist claims that institutions merely act as a function of the prevailing power hierarchy (classical realism), or are created by dominant powers during periods of hegemony (neorealism). Strong leadership is often seen as a precondition of collective action undertaken by entities such as states, corporations, international organisations, or non-governmental organizations (NGOS).

Yet, few studies clearly define or elaborate upon political agency in relation to institution building. In this regard, the work by Oran Young in the early 1990s stands out. ${ }^{10} \mathrm{He}$ distinguishes three forms of leadership required to solve or circumvent collective action problems that undermine the potential to achieve joint gains: structural leadership, entrepreneurial leadership, and intellectual leadership.

\footnotetext{
7 Daniel and Pollack (2001).

8 Op.cit p. 109.

9 Nye (2008).

10 Young (1991).
} 
Structural leadership is the translation of material power into bargaining leverage in international negotiations. Entrepreneurial leadership involves agenda setting, the invention of policy options, and alternative measures to compensate stakeholders in the achievement of a higher goal, whereas intellectual leadership relies upon the power of ideas to shape the thinking behind the principles underpinning institutional arrangements, guide understanding of the issues at stake, and orient policy towards alternative options. Young posits that all three forms of leadership were evident in negotiations over the establishment of diverse international regimes ranging from the environment to nuclear non-proliferation during the final decades of the 20th century.

\subsection{Structural Versus Custodial Leadership}

The above discussion suggests that the dynamic relationship between structural and collaborative forms of leadership is central to any analysis of institution building in practice. Structural leadership offers a useful lens for assessing how leaders negotiate power differentials in the absence of coercion. In questioning the decline of US hegemony in the late 1980s, Susan Strange proposed a general theory of structural power to account for the continuing US dominance of the global economy. In her seminal article written in 1987 she argued that structural power was manifest in a 'capacity to determine the terms' on which the rules and norms of the international system are realised, 'and to whom they are made available'. ${ }^{11}$ In terms of actual negotiating behaviour, a structural leader acts in the name of a party by forming coalitions and taking measures to prevent the emergence of blocking behaviour or counter coalitions. ${ }^{12}$ In this sense, power asymmetry is important, but not all determining.

In contrast, a focus upon collaborative leadership offers deeper insights into how leaders broker interests and on what basis. In addition to an emphasis upon creativity (entrepreneurship) and ideas (intellectual) as noted by Young, in the contemporary era it is increasingly evident that the political calculus over leadership should also stress the value of responsibility in the achievement of long-term goals. This is particularly relevant at a time when rising parochialism threatens to dilute the international policy agenda, thus diverting attention away from the realities of global interdependence and its political, social, and economic consequences. A focus upon custodial stewardship offers an additional means of achieving a vision beyond the immediacy of negotiations and short-term interests. ${ }^{13}$ In practice, this involves the brokering of national and collective interests towards the achievement of a long-term goal.

To illustrate the structural versus collaborative forms of leadership in greater detail let us now turn to a discussion of institution building initiatives in practice from an historical perspective. To avoid privileging successful institutional outcomes as the benchmark for leadership capacity, we shall consider both cases

\footnotetext{
11 Strange (1987).

12 Oran Young (1991). op.cit.

13 This idea is similar to that of great custodial responsibility in Reich and Lebow (2014).
} 
of success and failure in galvanizing collective action including the Law of the Sea Convention and the Multilateral Investment Agreement at the global level, and APEC and the TPP at the regional level.

\section{Political Leadership: Global Context}

\subsection{Law of the Sea Convention}

One of the reasons why empirical studies of leadership in global governance are limited is that they are difficult to reproduce on the basis of available materials. Despite the centrality of the Law of the Sea Convention in safeguarding maritime security between states, no complete record of the negotiations exists. We are, therefore, reliant upon the records of the negotiators themselves combined with process tracing of relevant documentation.

In general, the role of the League of Nations in international rulemaking is often overlooked on account of its collective failure to maintain peace during the interwar years. As a consequence, an initial attempt to codify the seas at the Hague Conference in 1930 is not well-known. In particular, the pioneering efforts by a group of jurists 'to chart the world' by defining ocean boundaries as well as the juridical status of territorial waters is largely invisible in the contemporary narrative on maritime governance. ${ }^{14}$ A second attempt to codify the scope of maritime jurisdiction on the high seas at the first and second conferences on the law of the sea held in Geneva in 1958 and 1960, respectively, is equally shrouded in secrecy.

It took a major international crisis with potentially devastating consequences to provoke a sense of urgency in the negotiations. At the height of the Cold War, the capability to launch nuclear missiles from military installations on the ocean floor posed the greatest existential threat to the world's oceans. In the face of intense superpower rivalry, Dr Arvid Pardo from the newly independent island state of Malta charted a new direction in the Law of the Sea negotiations by championing the inclusion of the seabed and ocean floor within the 'common heritage of mankind'. Based upon detailed scientific assessments, the new norm for safeguarding the maritime commons was given legal recognition in Resolution 2749 adopted by the General Assembly in 1970, and later applied in article 136 of UNCLOS.

In a major study on the negotiations, Robert Friedheim describes UNCLOS as 'the largest, longest, and most complex formal negotiation in modern times' covering all aspects of the use of the oceans for navigation, transit, overflight, maritime jurisdictional delimitation, oil and mineral exploitation, fisheries, environmental protection in the high and territorial seas, ocean science, and protection of the deep seabed. ${ }^{15}$ Representing the general mood of the delegations to the Third Conference on the Law of the Seas, President Tommy Koh referred to the

\footnotetext{
14 See Miller (1930).

15 Friedheim (1993).
} 
treaty as a 'monumental achievement of the international community second only to the adoption of the United Nations Charter.' 16

Following 9 years of negotiations, Ambassador Koh is generally credited with successfully marshalling disparate coalitions and forces behind a total package deal that culminated in the final comprehensive treaty on the law of the sea signed in 1982 at Montego Bay in Jamaica and entering into force in 1994. While it may be too much of an exaggeration to define his role on the basis of charismatic authority in classical terms, the combination of political expediency and creativity does provide an exemplary model of entrepreneurial leadership.

The political gridlock that emerged over the International Seabed Authority (ISA) is perhaps one of the best examples of the limitations of structural power. The ISA was vested with discretionary powers to govern the deep seabed beyond national jurisdiction on the basis of equitable principles that accorded developing states the right to share the benefits of a common heritage. Original proposals for mandatory technology transfer and the redistribution of profits from mining operations to developing states were blocked by major developed states including Italy, former West Germany, the United Kingdom, and the United States, leading to a renegotiation of the seabed regime at the final hour. The Chair of the American delegation to the Law of the Sea conference, Elliot Richardson, failed to produce a deep-seabed mining regime acceptable to the Reagan Administration, which eventually led to the US failure to accede to the convention-with continuing implications for maritime security today.

More positively, Ambassador Koh was able to build momentum and consensus for a creative agreement on seabed mining by introducing outside experts while balancing formal meetings with informal gatherings. An agreement signed just months before UNCLOS came into force granted stronger representation and higher production quotas for industrialised states, thus gaining broader consent. ${ }^{17}$

The Oceans regime provides an example of how the mix of intellectual and entrepreneurial leadership as defined by Oran Young led to a positive outcome that managed to overcome structural determinants. Structural leadership was present but less visible in comparison with other international regimes. A form of custodial leadership bringing together the President and Chairs of the three substantive committees together with the special representative of the Secretary-General was also evident in ensuring a consensus-based agreement. According to Alan Beesley, Chairman of Drafting Committee, 'mysterious dynamics of consultation within the so-called collegium' was responsible for bringing about a positive goal-oriented outcome. ${ }^{18}$ In his view, where the developed and developing countries worked together as partners, success was achieved. This form of leadership, aimed at a higher goal beyond the immediacy of the negotiations, was a critical thread in the

\footnotetext{
${ }^{16}$ Extract from the Official Records of the Third United Nations Conference on the Law of the Sea, Volume XVII, 193rd Meeting, A/CONF.62/SR.193, 10 December 1982, p. 5.

17 Agreement Relating to the Implementation of Part XI of the United Nations Convention on the Law of the Sea of 10 December 1982, UN Doc. A/RES/48/263, 28 July 1994.

18 Beesly (1983).
} 
successful outcome of the negotiations. It provides a vivid example of how a custodial form of leadership can work in practice.

\section{Multilateral Investment Agreement}

One of the most significant gaps in global governance today is the lack of a multilateral investment regime. The codification of protection measures for foreign investment has proven elusive over time, thus dislodging the commonly held assumption that bargaining over the economy is any less an intractable process than negotiating over security. Failed negotiations over a multilateral agreement on investment liberalisation dates back to the establishment of the Bretton Woods system in 1948. ${ }^{19}$ Plans for an International Trade Organization, known as the Havana Charter, drawn up by the Treasury Departments in the United States and the United Kingdom, sought to include provisions to protect foreign investment from expropriation and nationalization on the part of host states. ${ }^{20}$ Political pressure from the United States, however, was offset by the bargaining power of the capital importing states. In its final form, the text diluted the rights of foreign investors in favour of the right to implement appropriate safeguards against interference in the internal affairs of any member state. ${ }^{21}$

The inherent difficulties involved in balancing national security concerns and investor protection with the right to national development led to the swift abandonment of the treaty after 4 years leading to the more modest General Agreement on Tariffs and Trade (GATT), which eventually turned into the World Trade Organisation (WTO) in 1995.

International rulemaking over investment under GATT did not commence fully until the Uruquay Round of trade negotiations, culminating in a number of provisions to limit restrictive investment policies, relating to services and intellectual property in particular. ${ }^{22}$ The United States played a leading structural role in bringing about the conclusion of the General Agreement on Trade in Services that introduces a positive list approach for member states to open up their markets to foreign investors within specific sectors of the economy. ${ }^{23}$ However, dominating the global economy did not translate easily into dominating the rules over global investment. Negotiations over investment protection floundered, largely on account of the normative gap between liberal principles serving the interests of developed

\footnotetext{
19 Dattu (2000).

20 United Nations Conference on Trade and Employment Havana Cuba, 1947. Available at https://www. wto.org/english/docs_e/legal_e/havana_e.pdf.

21 Ryaz Dattu op.cit. p. 287.

22 See Agreement on Trade-related investment measures (TRIMS) April 15 1994, General Agreement on Trade in Services, (GATS) April 15 1994, and Agreement on Trade-Related Aspects of Intellectual Property Rights (TRIPS) April 15 1994. TRIMS requires all member countries to eliminate notified trade investment measures progressively over time, GATS aims to protect service providers exporting from other countries, and TRIPS protects intellectual property under trade.

23 Ryaz Dattu. op.cit. p. 294.
} 
nations and multinational enterprises (MNEs) and the national sovereignty concerns of developing states.

Against this backdrop, the failed attempt by the Organisation for Economic Cooperation and Development (OECD) to play a lead role in negotiating a comprehensive Multilateral Agreement on Investment (MAI), under the chairmanship of Frans Engering, is revealing of the limitations of a dual-track approach towards collaborative leadership that serves to reinforce rather than transcend political divisions. Following an ambitious plan to arrive at an agreement within 2 years (1995-1997), leaders of the negotiations, set out to establish a multilateral legal framework for foreign direct investment (FDI) open to accession by all states that included provisions for the settlement of disputes and promoted a level playing field for the national treatment of foreign investors. ${ }^{24}$

The entrepreneurial leadership offered by Mickey Kantor, former United States Trade Representative, and Sir Leon Brittan, then European trade commissioner, was pivotal in reaching a consensus over the importance of maintaining momentum over investment liberalisation under the broader mandate of the WTO. In this sense, the MAI was conceived of as a prerequisite to future WTO negotiations. In the words of Sir Brittan speaking to a business conference in 1995, 'I want to salute Mickey Kantor's part in helping us to reach that consensus. He, like me, is among the midwives of the WTO system. I believe that he, like me, shared the view that the broadest possible discussion as early as possible could only help to produce wide acceptance of strong international investment rules, as soon as they are available.' 25 Beyond this transatlantic collaboration, however, the entrepreneurial capacity of the negotiators was largely missing. As confirmed by Jan Huner, assistant to the Dutch chair of the negotiations, 'The main problem with the MAI is that its negotiators did not expect to have to sell it politically'. ${ }^{26}$

At the time, in stark contrast to the grindingly slow pace of negotiations within the WTO, the MAI initiative was hailed as a major breakthrough in setting the pace for the liberalisation of investment via the major developed nations, thus circumventing inevitable North-South divisions. ${ }^{27}$ However, major champions of the MAI, especially the United States, grossly underestimated the latent divisions amongst the major capital exporting countries as well as the groundswell of opposition rising from within the NGO community. In particular, allowing investors the freedom to move money in and out of countries without restrictions raised alarm bells. A central concern focused upon the right of investors to impartial international arbitration in the event of a dispute with a host state as stipulated under Chapter 11 of the NAFTA Agreement, thus privileging commercial interests over

\footnotetext{
24 OECD Multilateral Agreement on Investment Draft Consolidated Text DAFFE/MAI (98) 7 Rev 122 April 1998.

25 European Press Release Brussels 21 June 1995.

26 Katia Tieleman. 2000. 'The Failure of the Multilateral Agreement on Investment (MAI) and the Absence of a Global Public Policy Network,' United Nations Visions Project on Global Public Policy Networks, European Institute, p. 17.

27 For a comprehensive discussion of the cost and benefits of the MAI see Zdenek Drabek. 1998. 'A Multilateral Agreement on Investment: Convincing the Skeptics' World Trade Organization, Economics Research and Analysis Division, Staff Working Paper ERAD-98-05 June.
} 
environmental and social standards. ${ }^{28}$ Canada acted as a staunch advocate in favour of more progressive domestic legislation on account of its own experience in dealing with investor disputes with the US. France was the most vocal proponent of a cultural exemption clause that would help to protect its cultural industries. And the European Union sought preferential treatment for its members far beyond that of the signatories to the MAI. ${ }^{29}$ In the end, the highly charged public campaign to derail the MAI largely succeeded because NGOs allied themselves with other like-minded liberal states. ${ }^{30}$ Following an extended period of negotiation France withdrew in October 1998 and the talks collapsed. ${ }^{31}$

In recent years, the pace of investment liberalisation has emanated from below via the plethora of bilateral and regional investment agreements rather than from above. Aligned with the necessity of attracting foreign investment, over the past two decades developing countries have taken the lead in establishing reciprocal arrangements for foreign investment. ${ }^{32}$ In 1999 the number of bilateral investment treaties totaled $1857 .{ }^{33}$ Almost 20 years later that number has risen to $2363 .{ }^{34}$ China now leads the world in BITs (128) followed by the Czech Republic (113). However, the qualitative dimension of the provisions differs widely across the spectrum of reciprocal arrangements.

At the regional level, NAFTA continues to set the benchmark for high standards of investment protection supported by an investor-state dispute settlement procedure. Whether this should be seen as the exemplary model of global investment is a contentious question. In Asia, one of the major challenges facing the region is to establish stronger measures to safeguard investment while advancing environmental and labour standards. The lesson from the MAI experience is that political leadership requires a broader mandate with a strategy in place to ensure incremental gains over time and a clear vision of promoting the long-term goal of sustainable economic growth. In common with the issue of maritime security, a stronger emphasis upon custodial stewardship is needed to offset the limitations of structural power.

\section{Political Leadership Capacity: Regional Context}

Turning to the Asian regional context, the formation of APEC in the early 1990s and the recent attempts to establish the TPP offer further insights into the relationship between structural and collaborative forms of leadership in shaping institutional arrangements relating to trade, economic development, and investment.

\footnotetext{
28 Walter (2001), p. 59.

29 Zdenek Drabek. 1998. Op.cit.

${ }^{30}$ For an extended discussion of entrenched business lobbying in the making of international trade policy and the moderating influences of NGOs see Walter (2001).

31 For further discussion of the disputes over exemptions in the negotiations see Peter T. Muchlinski. 1999. 'The Rise and Fall of the Multilateral Agreement on Investment: Where Now?' The International Lawyer, vol. 34, no. 3, Foreign Law in Review, 1033-1053.

32 Ibid.

33 UNCTAD/ITE/IIA/2 Bilateral Investment Treaties 1959-1999. Available at: http://unctad.org/en/ Docs/poiteiiad2.en.pdf.

34 http://investmentpolicyhub.unctad.org/IIA.
} 


\subsection{APEC}

The official history of APEC reinforces the relevance of structural leadership and the utility of forming coalitions to pursue shared goals. Former Australian Prime Minister, Bob Hawke, first broached the idea of APEC in a speech in Seoul on 31 January 1989. Australia hosted the first annual meeting of trade ministers from 12 Asia Pacific economies (ASEAN 6 plus US, Canada, New Zealand, Australia, Japan, and Korea) in the same year, and played a leading role in promoting free trade and economic cooperation along the Pacific Rim. Former United States President Bill Clinton is credited with providing greater strategic vision in the direction of economic cooperation in the region, hosting the first APEC Summit in 1993 and establishing the practice of an annual APEC Economic Leaders' Meeting. ${ }^{35}$ Both leaders at the time demonstrated a charismatic pre-disposition towards the mission of open regionalism.

The unofficial history documented by those involved in the process of deliberations over the ideas and institutional arrangements facilitating Pacific regionalism reveals a more complex picture. Collaborative leadership resided in business networks, public intellectuals, and official representatives. Dating back to the 1960s, the idea of a Pacific free trade area was advanced by the Pacific Basin Economic Council (PBEC) and the Pacific Trade and Development Forum (PAFTAD) both established in 1968. Driven by concerns over preferential trading agreements, participants in these fora played a significant role in the evolution of government policy.

The idea of a Pacific Free Trade Area (PAFTA) originated in the work of Kiyoshi Kojima, a Professor of International Economics, at Hitotsubashi University who viewed the European Economic Community as a model for Asian economic development, but was also concerned that developed Pacific states would be left behind by greater European integration. Hence, his two objectives included the expansion of trade amongst Pacific countries and an increase in aid to Southeast Asia. $^{36}$ The concept was championed by Saburo Okita, a senior economic bureaucrat, and the Japanese Foreign Minister, Takeo Miki who led consultations over the establishment of a new regional organization similar to the OECD. ${ }^{37}$ Japanese entrepreneurship in regional economic governance at the official level was weakened by a failure to obtain consent from Southeast Asian Nations on account of Japan's past imperial history.

APEC in its institutional form started from modest beginnings; championed within academic meetings in Canberra hosted by Peter Drysdale at Australian National University (ANU) and Hugh Patrick from Yale University-both former students of Kojima. Drysdale was convinced by the importance of a Pacific economic community to counter-balance developments taking shape in Europe and he won the support of John Crawford, former Secretary of the Australian Department of Trade and Head of the Research School of Pacific Studies at the

\footnotetext{
35 https://www.apec.org.

36 Takashi (1999).

37 Okita (1984).
} 
ANU. ${ }^{38}$ It was this intellectual leadership that laid the groundwork for APEC under the political tutelage of Bob Hawke in 1989.

Broader support for a multilateral open trading system in the Asia Pacific consistent with the principles underpinning the GATT gathered momentum in the 1980s as a response to the imperative to keep pace with regional integration initiatives taken by the United States and Europe. In its final form, APEC emulated EU and NAFTA models of economic cooperation. Its broad based membership has been a critical factor in galvanizing support for collective action. The PRC, Hong Kong, Chinese Taipei joined in 1991, Mexico and Papua New Guinea followed in 1993, Chile acceded in 1994, and Peru, Russia, and Vietnam joined in 1998. While many questions remain over the effectiveness of this informal regional forum in meeting the complex requirements of the global economy, APEC can rightly claim status as the progenitor of regional economic cooperation in the Asia Pacific. Above all, the legacy of custodial leadership lies in the vision of open regionalism that continues to inspire a future generation of leaders seeking to re-balance national and global priorities.

\subsection{Trans-Pacific Partnership}

Current accounts of the TPP have a tendency to infer strong structural leadership on the part of the United States. This overlooks the collaborative aspects of the partnership approach as well as the complexity of the negotiations. In contrast to APEC, the origins of the TPP lie in a more formal government-sponsored process. At the APEC Leaders Summit in 2002, the so-called P4 (New Zealand, Chile, Singapore, and Brunei) launched the Trans-Pacific Strategic and Economic Partnership, facilitating next generation trade issues such as labour protection, environmental safeguards, and intellectual property rights. ${ }^{39}$ A unique feature of the partnership is the focus upon trans-continental cooperation between Asia and Latin America.

In 2008 the US announced it would join negotiations over investment and financial services, and subsequently took control over the negotiations for a comprehensive agreement. Under the structural leadership of President Obama, membership expanded to include Australia, Peru, Vietnam, Malaysia, and Japan. However, yet again in this case, the limits of structural power soon became evident.

The TTP is distinct from existing multilateral trade agreements in that it builds upon advanced Free Trade Agreements (FTAs) to address domestic regulations that affect trade and investment. ${ }^{40}$ The distributional benefits across member countries are, therefore, hotly disputed. Major sticking points include market access for sensitive products such as beef, diary, and rice, rules of origin for textiles and apparel, regulation of the digital economy, and services and investment to name but a few. ${ }^{41}$ As a consequence, the intellectual foundations of the partnership were

\footnotetext{
38 Drysdale (1984).

39 Lewis (2009).

40 Capling and Ravenhill (2011).

41 Schott et al. (2013).
} 
crucial in gaining support for collective action. In particular, Fred Bergsten and Jeffrey Schott from the Peterson Institute of International Economics provided intellectual leadership through the provision of macroeconomic analyses. However, reliable documentation on non-governmental inputs into the policy process is difficult to find.

The relatively short history of the TPP coupled with the current difficulties over sustaining leadership in the face of American withdrawal (with the stroke of a pen in January 2017) limits the development of a complete assessment. It is tempting to suggest that in this case charismatic leadership has played a role-for better, or for worse. President Donald Trump's declared mission to bring back jobs to the US may appear utopian to some, but it has clearly captured the imagination of a large number of the American people. ${ }^{42}$ It is also worth noting here that Trump's solemn promise "to make America great again for American workers" chimes with the sober analysis of a Nobel-prize winning economist. Joseph Stiglitz is equally a staunch critic of the TPP claiming that it is the worst trade agreement ever to be negotiated' on account of the investment provisions acting against the shift towards a low-carbon economy, workers' rights, and the sovereign concerns of host states. The question that needs to be asked is how does the TPP benefit the broader process of regional economic integration, and what is the best approach towards ensuring high political and economic standards of cooperation.

At the time of writing, it was unclear whether the TPP could be sustained in the absence of US participation, despite valiant efforts by Australia, Japan, and New Zealand to maintain momentum. As noted by Ling Shengli from the China Foreign Affairs University in Beijing, China has limited incentive to join the partnership, given its strategic concerns over status. ${ }^{43}$ Who leads the TPP is now an open question.

The ASEAN led Regional Cooperation Economic Partnership (RCEP) initiative offers an alternative model of regional integration. But in terms of addressing the problems of collective action it only serves as a weak form of political leadership because it does not demand higher environmental and labour standards. At a time of rising protectionism and concerns over economic inequities at the domestic level, leaders face a difficult political conundrum: extend the system of open regionalism and risk the build-up of environmental and social pressures spilling over into the economic and security arenas, or build a new system based upon the principles of qualitative economic growth that will strengthen the prevailing economic order but incur significant costs (both economic and political) in the process. In a more technical sense, the constraint on custodial leadership lies in what economists refer to as the discount rate in the minds of decision-makers that places immediate rewards before long-term benefits. ${ }^{44}$

\footnotetext{
${ }^{42}$ When signing the executive order to withdraw from the TPP President Trump tweeted 'we've been talking about this for a long time. It's a great thing for the American worker' See David Smith. Trump withdraws from the Trans-Pacific Partnership amid flurry of orders. The Guardian. 23 January 2017.

${ }^{43}$ Ling Shengli. Will China join TPP is not the question. China Daily. 20 March 2017.

44 The discount rate and net present value is based on a model of time preference. The general principle is that people prefer to receive benefits now rather than in the future.
} 
The Free Trade Area of the Asia Pacific (FTAAP) could also provide new momentum towards trade liberalisation and investment due to its broader geographical scope. Indeed, at the APEC Forum in 2014 President Xi Jinping announced support for pushing ahead with the FTAAP. However, without the inclusion of the world's least developed countries the risk is that this will draw a line between the haves and the have-nots at a time when structural economic inequality is a salient political concern for all states.

Above all, current governing arrangements to regulate foreign investment remain wholly inadequate to deal with the realities of the global political economy. In a speech to the MIKTA (Mexico, Indonesia, South Korea, Turkey, and Australia) group at the WTO in March 2017 the Director-General, Roberto Azevêdo, reinforced the importance of strengthening global investment policy to align with new contemporary realities such as the increasing role of developing countries in FDI, the rise of China as the second largest foreign investor after the United States, and the complex patterns of global supply chains. ${ }^{45}$

Collaborative leadership around trade facilitation in relation to specific issues provides a bright spot on the political horizon, and merits greater attention. For example, in 2014, 14 WTO members, including the US, China, and EU, concluded a plurilateral agreement to eliminate tariffs on environmental goods such as solar panels and wind turbines on a non-discriminatory basis. One leadership approach is to continue along a gradualist pathway in the hope that momentum can be sustained from below in the absence of a global steer from above. A second approach could be to build towards the broader goal of a global pact on sustainable investment. This would make a significant contribution to global governance by moving us beyond the traditional divide between investment protection and sustainable development concerns that has plagued international economic institutions since their inception.

\section{Conclusion}

To conclude, the analysis in this article suggests that power asymmetry does not condition political leadership in absolute terms. A theoretical focus upon legitimate authority forces us to look beyond a one-dimensional view of political leadership in global governance and consider alternative sources of leadership including the mobilisation of intellectual capital, entrepreneurship, and the stewardship of a goaloriented vision. At least on the basis of the cases presented, structural power alone does not translate easily into the rules of international conduct. It does, however, still matter.

On balance, it would seem that the trend towards collaborative leadership is positive, however, sustaining momentum is likely to be a difficult task. A stronger custodial form of leadership that moves beyond the negotiation of immediate interests may help to facilitate a long-term normative commitment. The major policy implication for the United States and China is that taking the lead in global

\footnotetext{
45 World Trade Organization Speech DG Roberto Azevêdo 20 March 2017. Available at https://www. wto.org/english/news_e/spra_e/spra_e.htm.
} 
governance, either jointly or multilaterally, will require brokering interests and values to align with long-term goals, without which it is difficult to see how we can escape from a perpetual state of action and reaction, let alone crisis.

Open Access This article is distributed under the terms of the Creative Commons Attribution 4.0 International License (http://creativecommons.org/licenses/by/4.0/), which permits unrestricted use, distribution, and reproduction in any medium, provided you give appropriate credit to the original author(s) and the source, provide a link to the Creative Commons license, and indicate if changes were made.

\section{References}

Alexandroff, Alan S., and Andrew F. Cooper. (eds) 2010. Rising States, Rising Institutions: Challenges for Global Governance. Washington, DC: Brookings Institution Press.

Beesly, Alan. 1983. The Negotiating Strategy of UNCLOS III: Developing and Developed Countries as Partners-A Pattern for Future Multilateral International Conferences. Law and Contemporary Problems 46 (2): 183-194.

Capling, Ann, and John Ravenhill. 2011. Multilateralising regionalism: what role for the Trans-Pacific Partnership Agreement? The Pacific Review 24 (5): 553-575.

Cooper, Andrew F., and Agata Ant Kiewicz. 2008. Emerging Powers in Global Governance: Lessons from the Heiligendamm Process. Waterloo: Wilfrid Laurier University Press.

Daniel L. Byman and Kenneth M. Pollack. 20001. Let Us Now Praise Great Men: Bringing the Statesman Back In. International Security. 25 (4): 107-146.

Dattu, Ryaz. 2000. A Journey from Havana to Paris: The Fifty-Year Quest for the Elusive Multilateral Agreement on Investment. Fordham International Law Journal 24: 274-314.

Drysdale, Peter. 1984. The Pacific Trade and Development Conference: A Brief History Pacific Economic Papers, no.112, Australia-Japan Research Centre, Australia National University.

Friedheim, Robert L. 1993. Negotiating the New Ocean Regime, ix. Columbia: University of South Carolina Press.

Gerth, H.H., and C. Wright Mills. 1958. XVII The Chinese Literati in From Max Weber: Essays in Sociology. New York: Oxford University Press.

Lewis, M.K. 2009. Expanding the P-4 trade agreement into a broader trans-pacific partnership: implications, risks and opportunities. Asian Journal of WTO and International Health Law and Policy 4(2): 401-422.

Miller, David Hunter. 1930. The Hague Codification Conference. American Journal of International Law 24 (4): 674-693.

Nye Jr., Joseph S. 2008. Powers to Lead: Soft, Hard, and Smart. New York: Oxford University Press.

Okita, Saburo. 1984. Pacific Regional Cooperation. In Policy and Practice: Essays in Honour of Sir John Crawford, eds. L.T. Evans, and J.D.B. Miller. Canberra: ANU Press.

Owen, David, and Tracy B. Strong. 2004. Max Weber: The Vocation Lectures Science as Vocation, Politics as Vocation, 34. Indianapolis: Hackett Publishing Company.

Reich, S., and R.N. Lebow. 2014. Good-Bye Hegemony: Power and Influence in the Global System. Princeton: Princeton University Press.

Schott, Jeffrey J., Kotschwar, Barbara., and Muir, Julia. 2013. Understanding the Trans-Pacific Partnership. Washington DC: Peterson Institute for International Economics.

Strange, Susan. 1987. The Persistent Myth of Lost Hegemony. International Organization 41 (4): 551-574.

Takashi Terada. 1999. The Japanese Origins of PAFTAD: The Beginning of an Asian Pacific Economic Community, Pacific Economic Paper no. 292. Australia-Japan Research Centre, Australia National University.

Walter, Andrew. 2001. NGOs, Business, and International Investment: The Multilateral Agreement $n$ Investment, Seattle and Beyond. Global Governance 7: 51-73.

Young, Oran R. 1991. Political Leadership and Regime Formation: on the Development of Institutions in International Society. International Organization 45(3): 281-308 (Summer). 
Katherine Morton is the Chair and Professor of China's International Relations at the University of Sheffield. Prior to her appointment, she was the Associate Dean for Research at the College of Asia and the Pacific, Australian National University and a Senior Fellow in the Department of International Relations, ANU. She has published widely on China's international relations, global governance, transnational security, the environment and climate change, food security, and maritime security. Her current book project with Oxford University Press examines the likely impacts of China's rising international status upon the evolving system of global governance. 